\title{
SUKSESI PADA PERUSAHAAN KELUARGA: STUDI EKSPLORASI PADA INDUSTRI BATIK PEKALONGAN
}

\author{
Achmad Sobirin (achmad.sobirin@uii.ac.id) \\ Nuzul Fitriawaty Basri (nz.fitria@gmail.com) \\ Paska Sarjana Fakultas Ekonomi Universitas Islam Indonesia, Jogjakarta
}

\begin{abstract}
Abstrak
Suksesi merupakan topik menarik dalam lingkup kajian perusahaan keluarga khususnya dalam lingkup industri batik Pekalongan karena rata-rata perusahaan batik di Pekalongan berlangsung secara turun temurun. Perusahaan keluarga yang menjadi bahan penelitian ini adalah empat perusahaan batik yang telah berdiri selama lebih dari 15 tahun dan juga telah atau sedang melakukan proses suksesi, yakni: Batik Tobal, Batik Huza, Batik HF dan Batik Pesisir. Pelaku usaha Batik Tobal dan Batik Huza merupakan pendiri dan pemilik perusahaan (generasi pertama), sedangkan pelaku usaha dari Batik HF dan Batik Pesisir merupakan generasi kedua yang telah melewati proses suksesi. Metode yang digunakan dalam penelitian ini adalah kualitatif deskriptif dengan melakukan observasi, Focus Group Discussion (FGD), wawancara mendalam dan studi pustaka. Oleh karena hasil dari penelitian ini adalah analisis deskripsi tentang perencanaan dan proses suksesi dalam perusahaan keluarga yang berada dalam satu industri yang sama yaitu industri batik di Pekalongan, hasil penelitian ini dengan demikian tidak dapat digeneralisir ke semua pelaku usaha batik lainnya.
\end{abstract}

Temuan penelitian menunjukkan bahwa ke-empat pelaku usaha industri batik tersebut tidak memiliki perencanaan suksesi tertulis, hanya beberapa dari mereka mengakui telah mempersiapkan anak-anak mereka dengan memperkenalkan usaha batik sejak kecil. Namun para pemilik cenderung memilih anak-anak yang memiliki kecintaan kepada batik dan perusahaan, seperti yang dilakukan oleh pendiri batik Tobal dan batik HF. Pendiri batik Huza juga mengakui belum mempunyai rencana untuk suksesi, walaupun anak-anak telah dilibatkan dalam pengelolaan batik Huza, sementara pemilik batik pesisir yang merupakan pelaku usaha termuda belum berencana melakukan suksesi karena anak-anaknya yang masih kecil. Meskipun demikian, pemilik batik Pesisir mengakui telah memiliki strategi regenerasi jika satu saat akan melakukan suksesi ke generasi ketiga.

Dari studi eksplorasi ini bisa disimpulkan bahwa anak-anak generasi penerus tidak disiapkan sebagai calon pengganti. Untuk menjadi pengganti mereka cenderung belajar dari lingkungan yang sudah terbentuk karena secara tidak langsung diberi kesempatan yang sama untuk terlibat di dalam manajemen perusahaan, diberikan porsi tanggungjawab masing-masing, sementara pendiri masih memegang peranan yang besar terutama dalam hal pengambilan keputusan dan kebijakan bisnis.

Kata kunci : Perusahaan Keluarga ; Suksesi ; Perencanaan Suksesi ; Proses Suksesi

\section{Pendahuluan}

Perusahaan keluarga sejatinya adalah pertemuan antara dua institusi sosial, yakni institusi bisnis dan keluarga (Susanto, 1996). Keduanya memiliki nilai-nilai dan tujuan yang bertolak belakang. Hubungan dalam bisnis bersifat rasional, sementara dalam keluarga bersifat 
emosional. Menurut Susanto (2006) ciri khas bisnis keluarga dibandingkan bisnis lainnya terutama terletak pada kepemimpinan dan kontrol yang akan diwariskan pada generasi berikutnya. Berdasarkan data BPS (2007) yang telah menyelenggarakan Survey Ekonomi Nasional (Susenas) di tahun 2006, di Indonesia terdapat 48.929 .636 perusahaan; 90,95\% diantaranya dapat dikategorikan sebagai perusahaan keluarga. Data SUSENAS juga menyebutkan bahwa perusahaan keluarga menyumbang 53,28\% dari GDP dan menyerap 85.416.493 orang sebagai tenaga kerja atau 96,18\% dari seluruh angkatan kerja (Wahjono, 2009). Catatan penting tentang perusahaan keluarga adalah saat ini banyak perusahaan keluarga di Indonesia yang mampu bertahan hingga generasi berikutnya dan masuk dalam pasar modal seperti Bakrie, Kalla Group, Gudang Garam dan Sampoerna.

Di dalam bisnis perusahaan keluarga memang lazim terjadi tongkat estafet kepemimpinan dari generasi pertama kepada generasi kedua dan seterusnya. Hal yang krusial dalam perusahaan keluarga adalah pergantian pucuk pimpinan (suksesi). Penelitian mengenai suksesi dalam perusahaan keluarga bukan hal baru di Indonesia. Penelitian sejenis misalnya telah dilakukan oleh Evie Hikmahwati dan Ananda Sekarbumi. Evie Hikmahwati (2006) melakukan penelitian dengan menganalisa perumusan suksesi dan regenerasi pada perusahaan keluarga Al-Fajar. Al-Fajar merupakan produsen sarung tenun ATBM tipe craftmanship skala kecil untuk memenuhi permintaan pasar domestik dan ekspor. Selain itu, Ananda Sekarbumi (2001) melakukan penelitian tentang suksesi dengan menganalisis proses suksesi dari 20 perusahaan keluarga yang berada di Jakarta.

Proses suksesi tidak hanya terjadi di perusahaan keluarga kategori besar, akan tetapi juga dialami oleh perusahaan yang termasuk dalam usaha kecil dan menengah. Salah satunya adalah perusahaan keluarga yang bergerak di industri batik. Pertanyaan yang masih tersisa adalah bagaimana pola suksesi tersebut yakni bagaimana model perencaan dan proses suksesi berjalan.

Penelitian tentang suksesi pada industri batik penting karena beberapa alasan berikut. Pertama, batik telah mendapat pengakuan dari UNESCO sebagai warisan budaya tak benda asli Indonesia. Oleh karena itu pelestarian batik bukan hanya menjadi tanggungjawab pelaku industri saat ini tetapi juga menjadi tanggungjawab kita semua termasuk generasi mendatang. Artinya, tanpa ada estafeta kepemimpinan mustahil batik bisa dilestarikan. Kedua, khususnya bagi masyarakat Pekalongan dan Indonesia pada umumnya, batik telah menjadi budaya bukan sekedar aspek ekonomi meski harus diakui bahwa sebagaian besar keluarga di Pekalongan bisa dikatakan hidup dari batik dan usaha-usaha lain yang terkait. Estafeta kepemimpinan dengan demikian sekaligus akan menjaga kelestarian budaya dan kesejahteraan ekonomi.

Industri batik di Pekalongan ini didominasi oleh tiga etnis pengusaha, yaitu Jawa, Cina dan Arab. Sebagian besar usaha batik tersebut merupakan warisan keluarga turun temurun. Jadi jika satu keluarga sudah menjalankan usaha batik maka keturunan lainnya pun akan bergerak dalam bidang ini. Menurut pengusaha batik dari etnis Jawa, salah satu alasan terkuat mengapa mereka meneruskan usaha keluarga di industri batik karena rasa tanggungjawab untuk meneruskan perusahaan keluarganya, meski tidak mudah meneruskan perusahaan keluarga secara turun temurun (Sobirin, 2012). Oleh karena itu suksesi merupakan satu agenda yang sangat penting bagi perusahaan keluarga. Perencanaan dan proses suksesi masing-masing pengusaha batik di Pekalongan pasti berbeda satu sama lain. Untuk itu, mempersiapkan generasi penerus di masa datang harus dilakukan dengan perencanaan yang matang dan proses yang tidak instan. 


\section{Kajian Pustaka}

\section{Teori Perusahaan Keluarga}

Perusahaan disebut sebagai bisnis keluarga jika dua atau lebih anggota keluarga mengontrol kondisi keuangan perusahaan dan organisasi dan akan diakui sebagai bisnis keluarga jika ada setidaknya dua generasi yang terlibat dalam bisnis dan mereka dipengaruhi kebijakan organisasi (Tambunan, 2008). Dari sudut pandang ini, bisnis keluarga berarti bisnis yang dimiliki, dikendalikan dan dioperasikan oleh satu atau lebih anggota keluarga. Definisi lain tentang bisnis keluarga menurut Chua, Sharma dan Chrisman (2009) adalah bisnis diatur dan/atau dikelola pada bentuk dasar, secara berkelanjutan dan berpotensi lintas generasi, dan mungkin mengejar visi formal atau implisit bisnis yang dipegang oleh anggota keluarga yang sama atau sejumlah kecil keluarga.

Menurut Susanto (2000) terdapat dua tipe Perusahaan Keluarga, yaitu: 1) Family Owned Enterprise (FOE), yaitu perusahaan yang dimiliki oleh keluarga, namun dikelola oleh profesional yang berasal dari luar lingkaran keluarga. Peran keluarga hanya sebagai pemilik dan tidak melibatkan diri dalam operasi secara langsung, 2) Family Business Enterprise (FBE), yaitu perusahaan yang dimiliki dan dikelola oleh keluarga pendirinya. Ciri perusahaan tipe ini adalah posisi-posisi kunci dalam perusahaan dipegang oleh anggota keluarga.

Pada perusahaan keluarga tujuan yang paling menantang adalah membangun dan mempertahankan keselarasan terbaik antara perusahaan, keluarga dan kepemilikan. Seperti kita ketahui, banyak gaya yang berbeda dalam memepengaruhi orang lain. Hoover \& Hoover (1999) dalam Sobirin (2012) menggambarkan terdapat dua jenis gaya kepemimpinan yaitu Push and Pull Leaders. Push leader biasanya terlihat kharismatik dan mempimpin dengan pesona personal dan memiliki daya tarik. Mereka kadang-kadang disebut sebagai "Diktator baik hati". Sebaliknya, Pull leader, menyatu dengan kelompok, bekerja keras untuk membangun kesepakatan dan komitmen kelompok. Mereka sering disebut sebagai "pelatih" atau "cheerleader".

Menurut Tambunan (2009) seperti bisnis pada umumnya, bisnis keluarga juga memiliki beberapa keuntungan dan kerugian. Keuntungan adalah di bidang keuangan dan budaya organisasi. Keuntungan keuangan adalah: kemerdekaan tingkat tinggi berarti tidak ada tekanan pasar saham, tidak ada yang mengambil keuntungan milik keluarga (tidak ada pihak lain untuk berbagi keuntungan) dan tidak ada yang mengambil alih resiko. Oleh karena itu keputusan keuangan bisa dilakukan lebih cepat. Manfaat lainnya adalah kemungkinan keuntungan tersebut untuk digunakan dalam ekspansi bisnis atau re-investasi bisnis. Keuntungan budaya organisasi adalah budaya akan menyerap lebih cepat. Hal ini disebabkan ada cara intensif dalam mengkomunikasikan nilai dan budaya di antara anggota keluarga, seperti di rumah dan di kantor juga. Secara umum, anggota keluarga yang terlibat dalam bisnis keluarga memiliki kebanggaan terhadap generasi pendahulu mereka sehingga budaya organisasi akan lebih solid. Keuntungan lain dari bisnis keluarga adalah pemahaman awal tentang bisnis dari anggota keluarga dan yang terakhir adalah birokrasi kecil dan fleksibel.

Sementara itu, kelemahan bisnis keluarga adalah: bisnis keluarga kadang-kadang menjadi sebuah organisasi membingungkan terutama ketika anggota keluarga yang tidak terlibat dalam kegiatan bisnis justru dapat mempengaruhi bisnis demi alasan keluarga. Kerugian lain dari bisnis keluarga adalah kemungkinan sindrom anak manja atau toleransi yang tinggi 
untuk anggota keluarga yang tidak kompeten tetapi dilibatkan dalam kegiatan bisnis lebih disebabkan karena alasan pribadi. Beberapa masalah keuangan juga dianggap sebagai kelemahan dari bisnis keluarga, misalnya pembatasan untuk mengakses pasar saham. Bisnis keluarga biasanya bereaksi enggan terhadap perubahan dan praktik transformasi karena peran dominasi sang pendiri. Kaku terhadap perubahan adalah alasan utama mengapa bisnis keluarga cenderung berhenti sampai generasi pertama.

\section{Suksesi}

Menurut Handler (1994) suksesi dalam bisnis keluarga didefinisikan sebagai "berlalunya tongkat kepemimpinan dari pemilik pendiri untuk pengganti yang lebih baik, baik dari anggota keluarga maupun non-keluarga, yaitu manajer professional". Suksesi tidak hanya satu langkah dari menyerahkan tongkat estafet, tapi merupakan proses panjang dari waktu ke waktu, bahkan dimulai sebelum ahli waris memasuki bisnis. Suksesi bisnis keluarga adalah proses untuk kelanjutan bisnis keluarga yang turun dari generasi tua ke generasi yang lebih muda, termasuk didalamnya warisan properti, hak saham, operasional, reputasi dan status (Hania, 2012). Patricia dari The Jakarta Consulting Group mengatakan ada tiga alasan yang menjadi landasan kuat untuk mendorong suksesi di perusahaan keluarga. Pertama, karena keberlangsungan kepemimpinan bisnis penting untuk disiapkan agar tidak terjadi Prince Charles Syndrome. Pangeran Charles yang sudah berusia lebih dari 50 tahun masih tetap sebagai putra mahkota dan tidak pernah tahu kapan dia akan menjadi raja. Kedua, pentingnya suksesi di perusahaan keluarga adalah apabila generasi pertama pensiun atau meninggal dunia, perusahaan diharapkan tetap eksis dan berjalan lancar. Ketiga, untuk menjaga harmoni keluarga.

Karakteristik suksesi yang sukses menurut Cater III (2006) adalah sebagai berikut:

a. Planning and letting go.

Perencanaan merupakan aktifitas kunci dalam manajemen. Incumbent (pemilik-pendiri) harus rela menyesuaikan organisasi agar sesuai dengan keterampilan penerus. Kadangkadang perusahaan dapat dibagi menjadi sekelompok perusahaan terkait, tapi independen agar sesuai dengan kebutuhan generasi berikutnya.

b. Taking the reins.

Kredibilitas merupakan kunci untuk mendapatkan status legitimasi di perusahaan untuk penggantinya. Penerus pengganti harus memperoleh kredibilitas dalam perusahaan dengan membuktikan kemampuannya kepada manajer perusahaan dan karyawan. Untuk mendapatkan kredibilitas, banyak pengamat percaya bahwa yang terbaik bagi anggota keluarga baru adalah bekerja untuk bisnis lain sebelum memulai dengan perusahaan keluarga. Tujuannya agar pengganti mendapatkan pengalaman bisnis, kepercayaan diri, dan ditambah pandangan lingkungan bisnis.

c. Servant leadership.

Prinsip dari servant leadership adalah mendahulukan pelayanan kepada orang lain sehingga pada akhirnya jumlah pengikut terus bertambah. Oleh karena itu, pemimpin jenis ini tidak mencari kebesaran diri atau kekuasaan atau ketenaran. Sebaliknya, pemimpin mencoba secara positif mempengaruhi kinerja para pengikut, membangun organisasi lebih baik, dan mengambil pandangan jangka panjang untuk kemajuan organisasi. 


\section{Perencanaan Suksesi (Succession Planning)}

Rencana suksesi merupakan masalah strategis dalam bisnis milik keluarga (Ibrahim et al., 2001). Menurut Chua et al., (2003) perencanaan suksesi dalam perusahaan keluarga penting untuk mencapai sukses karena dua alasan. Pertama, kegiatan yang berkaitan dengan perencanaan suksesi merupakan bagian dari proses suksesi. Kedua, perencanaan suksesi diyakini dapat meningkatkan probabilitas dari suksesi yang sukses. Proses perencanaan suksesi terdiri dari komponen diskrit berikut antara lain: Memilih dan melatih penggantinya, mengembangkan rencana visi atau strategis untuk perusahaan setelah suksesi, mendefinisikan peran incumbent, mengkomunikasikan keputusan untuk stakeholder kunci dan perencanaan suksesi ini diharapkan dapat membantu meningkatkan probabilitas keberhasilan untuk proses suksesi.

Menurut Wijaya (2011) pola perencanan suksesi manajemen puncak antara lain :

- Planned Succesion. Perencanaan suksesi yang terfokus pada calon yang telah dipersiapkan untuk menduduki posisi kunci.

- Informal Planned Succession. Perencanaan suksesi yang lebih mengarah pada pemberian pengalaman dengan cara memberikan posisi di bawah "orang nomor satu" dan secara langsung menerima perintah dan petunjuk dari orang tersebut.

- Unplanned Succesion. Peralihan pimpinan puncak kepada penerusnya berdasarkan keputusan pemilik dengan mengutamakan pertimbangan-pertimbangan pribadi.

Rencana suksesi seharusnya tidak hanya mengidentifikasi calon potensial, tetapi juga alasan mengapa calon disukai untuk nominator lain. Dua kondisi, yang penting untuk suksesi untuk melanjutkan sebagaimana dimaksud, adalah kesediaan penerus untuk menunjukkan komitmen jangka panjang untuk kepentingan bisnis dan atau kemampuannya untuk mendapatkan pengetahuan yang diperlukan, keterampilan, dan kompetensi dibutuhkan untuk mengelola dalam rentang waktu yang terbatas menjelang generasi pertama pensiun. Karena itu, perencanaan suksesi juga membutuhkan komitmen dari penerus (Lee, Jasper, dan Goebel, 2003).

\section{Proses Suksesi (Succession Process)}

Isu suksesi merupakan isu yang sangat emosional karena hasilnya sangat memberikan pengaruh bagi anggota keluarga. Suksesi bisnis keluarga adalah proses pengelolaan alih generasi dan kepemilikan bisnis untuk generasi berikutnya dari anggota keluarga. Sebagian besar (kira-kira 84 persen) dari perusahaan bisnis keluarga tidak berniat untuk melewati kontrol bisnis ke generasi berikutnya yang merupakan anggota keluarga, dikarenakan kebanyakan dari mereka belum siap, karena menurut mereka suksesi terjadi hanya satu kali dalam satu generasi (Chrisman et al., 2009). Lebih lanjut, peneliti bahkan memperkirakan bahwa hanya satu hingga tiga perusahaan bisnis keluarga yang melakukan suksesi ke generasi kedua.

Proses suksesi dimulai ketika penggantinya memasuki perusahaan dan ketika generasi tua mulai berhenti dan diakhiri dengan pensiun. Handler (1992) merumuskan tentang tiga tahapan dalam proses suksesi antara lain :

1) Periode pengembangan individu, dimana individu telah bekerja setidaknya bekerja secara paruh waktu / part-time dalam bisnis perusahaan,

2) Periode keterlibatan dalam bisnis, dimana individu telah terlibat secara penuh dengan bekerja full-time dalam bisnis perusahaan, 
3) Tahapan suksesi kepemimpinan, dimana individu telah memiliki tanggungjawab atau telah memiliki jabatan sebagai "presiden".

Pada saat proses suksesi, kemungkinan untuk terjadinya konflik kepentingan sangat besar. Karena itu, untuk melanjutkan proses suksesi, tidak hanya pemegang jabatan dan penerus pengganti yang puas dalam proses, akan tetapi anggota keluarga yang lain seperti saudara kandung (Cater III \& Justis, 2009) harus merasakan hal yang sama. Oleh akrena itu jika ada beberapa anggota keluarga dengan generasi yang sama, kebutuhan atas setiap individu juga harus dipertimbangkan. Pimpinan keluarga dalam perusahaan multigenerasi harus mengembangkan proses untuk mengurangi konflik tersebut.

\section{Metodologi Penelitian}

Pembahasan metodologi untuk penelitian ini dimulai dari pemaparan unit analisa, metode pengumpulan data, instrumen penelitian, dan metode analisa data (Sobirin, 2012).

\section{- Unit Analisa}

Unit analisa dari penelitian ini adalah organisasi. Penelitian ini dilakukan pada beberapa perusahaan keluarga dalam konteks industri batik Pekalongan.

\section{- Metode Pengumpulan Data}

Pengumpulan data dalam penelitian ini menggunakan dua sumber data yaitu data primer dan data sekunder.

1. Pengumpulan data primer dilakukan antara lain melalui:

a. Observasi

Observasi diperlukan untuk menganalisis fakta empiris yang diteliti dalam penelitian ini yaitu dengan pengamatan langsung terhadap pelaku usaha batik yang terpilih di industri batik Pekalongan. Data yang diperoleh dari observasi ini akan digunakan untuk mendukung hasil analisa yang diperoleh dari teknik pengumpulan data lain.

b. Wawancara secara mendalam.

Wawancara secara mendalam dengan pelaku usaha batik (pendiri dan suksesor), untuk memperoleh informasi tentang perencanaan dan proses suksesi dalam perusahaan batik mereka.

c. Focus Group Discussion (FGD)

FGD akan melibatkan pelaku usaha industri batik (pendiri dan penerus / suksesor). Teknik ini dilakukan untuk memperdalam informasi yang diperoleh dari observasi dan wawancara.

2. Data sekunder dilakukan melalui studi pustaka. Dengan menggunakan studi pustaka diharapkan peneliti dapat membangun landasan teori tentang perencanaan dan proses suksesi dalam perusahaan keluarga pada umumnya dan pelaku usaha batik pada khususnya. Sumber dari studi pustaka ini bisa berasal dari artikel dan karya ilmiah yang dipublikasikan di dalam jurnal ilmiah dan media lainnya, dokumen yang dimiliki pelaku usaha batik, data-data terpublikasikan melalui media internet yaitu dari Biro Pusat Statistik Jawa Tengah dan Disperindagkop Pekalongan.

\section{- Metode analisis data}

Penelitian ini merupakan penelitian deskriptif - kualitatif yang memberikan gambaran tentang profil pelaku usaha batik di Pekalongan berikut perencanaan dan proses suksesi yang menjadi dasar penyusunan dan sebagai hasil akhir dari penelitian ini. Untuk kepentingan tersebut, maka analisa didasarkan pada hasil kajian studi pada beberapa pelaku usaha batik dalam konteks industri batik Pekalongan. 


\section{- Uji Validitas dan Reabilitas}

Dalam penelitian kualitatif, uji Validitas dan Reabilitas sering dinamakan uji kredibilitas. Uji kredibilitas yang digunakan dalam penelitian ini, yaitu metode Triangulasi. Triangulasi adalah suatu pendekatan analisa data yang mensintesa data dari berbagai sumber. Dalam penelitian ini, selain melakukan wawancara dengan narasumber utama yaitu pendiri-pemilik pelaku usaha batik, juga melakukan wawancara dengan narasumber lain. Peran narasumber tambahan ini untuk memperkuat pernyataan yang telah diberikan oleh narasumber utama dan juga mendapatkan informasi yang dibutuhkan dan belum diperoleh dari narasumber utama.

\section{Suksesi Perusahaan Keluarga pada Industri Batik Pekalongan}

Kota Pekalongan adalah salah satu kota di pesisir pantai utara Provinsi Jawa Tengah. Kota Pekalongan mendapat julukan kota batik. Hal ini tidak terlepas dari sejarah bahwa sejak puluhan dan ratusan tahun lampau hingga sekarang, sebagian besar proses produksi batik Pekalongan dikerjakan di rumah-rumah. Akibatnya batik Pekalongan menyatu erat dengan kehidupan masyarakat Pekalongan. Batik telah menjadi nafas penghidupan masyarakat Pekalongan dan terbukti tetap dapat eksis dan tidak menyerah pada perkembangan jaman, sekaligus menunjukkan keuletan dan keluwesan masyarakatnya untuk mengadopsi pemikiran-pemikiran baru.

Perjumpaan masyarakat Pekalongan dengan berbagai bangsa seperti Cina, Belanda, Arab, India, Melayu dan Jepang pada zaman lampau telah mewarnai dinamika pada motif dan tata warna seni batik. Akibatnya tumbuh beberapa jenis motif batik hasil pengaruh budaya dari berbagai bangsa tersebut yang kemudian sebagai motif khas dan menjadi identitas batik Pekalongan. Batik sebagai kerajinan produk budaya pada akhirnya juga berkembang menjadi komoditi bisnis. Dalam penelitian ini, empat pelaku usaha batik yang hadir dalam FGD adalah pemilik dari Batik Tobal, Batik Huza, Batik HF dan Batik Pesisir.

\section{Latar Belakang Perusahaan}

\section{Batik Tobal}

Batik Tobal merupakan salah satu perusahaan batik yang berkembang dan berhasil dengan menerapkan strategi langsung membidik pasar ekspor (pasar internasional). Batik Tobal didirikan oleh pasangan suami - istri Fatchiyah A. Kadir dan Achmad Oemar Basyarahil. Bu Fat, demikian biasa disapa, memulai karir bisnis batik pada tahun 1971 dengan menjadi pengepul batik yang kemudian diekspor. Bu Fat merupakan generasi pertama dalam perusahaan batik Tobal. Orangtua beliau bergerak di kerajinan tenun (sebagai pengusaha tenun ATBM), tidak hanya tenun dari bahan kain, juga mengambil dari serat daun pisang, bambu, serat nanas, dan enceng gondok. Batik Tobal mengkhususkan pada produksi batik dalam bentuk pakaian jadi dan lebih focus pada batik "fashion".

Desain batik Tobal diakuinya sebagai batik kontemporer, beliau memasukkan unsur - unsur motif etnis sesuai permintaan pelanggan, missal motif etnis aborigin untuk pasar Australia, motif hawai bahkan motif Indian. Pada tahun 2007, setelah 30 tahun mengembangkan bisnis batik Tobal, kondisi ekonomi global dan keamanan Indonesia yang terpuruk saat itu dengan adanya peristiwa "bom bali" sangat mempengaruhi produksi batik dan penurunan permintaan dari klien luar negeri. Untuk mempertahankan bisnis batik Tobal yang telah dibangunnya selama puluhan tahun, bu Fat akhirnya memutuskan untuk memasarkan batik Tobal di dalam 
negeri. Bu Fat mengakui bahwa beliau adalah pemain baru di lokal. Berbicara mengenai suksesi perusahaan di Batik Tobal, menurut bu Fat, regenerasi merupakan satu proses yang wajib dilakukan agar perusahaan keluarga tetap bertahan. Dari 4 (empat) anak, bu Fat melihat ketertarikan dan kecintaan 2 (dua) anaknya pada batik. Dua anak ini pernah bekerja di perusahaan ekspor impor dan masih dalam industri kerajinan. Setelah 3-4 tahun bekerja di tempat lain, tahun 2007 anak-anak kembali dan mulai melibatkan diri.

\section{Batik Huza}

Pendiri dan pemilik batik Huza adalah bapak Husein Muhammad Assegaf. Pak Husein mengatakan bahwa beliau bukan dari orangtua pengusaha batik. Batik Huza adalah batik Pekalongan yang didirikan pada tahun 1985 dan berlokasi di Klego, Pekalongan. Nama batik Huza diambil dari singkatan nama suami istri Husein - Zakiah. Beliau memiliki 11 orang anak. Pak Husein tidak memproduksi batik karena menurutnya memproduksi batik membutuhkan waktu sangat panjang, satu kain batik bisa selesai dalam tiga bulan. Selain itu beliau juga mempertimbangkan beberapa kendala misal pengaruh cuaca dan masa libur yang tidak tangung-tanggung bisa satu bulan jika hari raya Idul Fitri tiba.

Tujuan pak Husein berdagang adalah mencari keuntungan dan untuk menyekolahkan anak. Pak Husein membeli bahan kain batik kemudian dipotong dan kirim ke desa-desa, menyerahkannya ke penjahit dan memilah-milah mana kain yang bisa dijahit. Untuk mengetahui minat konsumen, beliau memberi contoh barang ke toko-toko, kemudian menghitung pakaian apa yang paling sering dipakai masyarakat. Beliau kemudian berkesimpulan “daster". Dari situlah Batik Huza dimulai. Saat ini batik Huza telah membuat bermacam model pakaian jadi dari kain batik pekalongan. Batik Pekalongan Huza memiliki corak khas tersendiri yaitu hitam putih dan juga memproduksi batik khas Pekalongan yang berwarna cerah. Mengenai suksesi, hingga saat ini pak Husein belum merasa perlu untuk menyiapkan pengganti. Pak Husein memiliki 11 orang anak. Semua anak diberikan kebebasan dalam memilih pendidikan dan pekerjaan.

\section{Batik HF}

Batik HF ini dipimpin oleh Haji Muhammad Jamil. Beliau merupakan pemimpin generasi ke2 dan berdasarkan penuturan beliau sedang mempersiapkan generasi ke-3. Orangtua Pak Haji (demikian biasa disapa) merupakan pembatik sungguhan, akan tetapi hampir sama dengan alasan pak Husein (batik Huza) bahwa dia merasa untuk memproduksi batik memerlukan waktu yang terlalu lama sementara beliau menganggap dirinya tidak sabaran. Jika orangtua Haji Jamil membuat sarung batik maka Haji Jamil lebih memilih untuk menjual batik dalam bentuk pakaian jadi.

Batik HF berdiri pada tahun 1998. Batik HF merupakan batik yang special untuk dijual di tempat-tempat wisata atau disebutnya batik wisata. Haji Jamil menyebut batik yang dijualnya sebagai "batik srampangan / abstrak". Nama dari batik HF ini merupakan pemikiran dari pemiliknya untuk memberikan identitas yang kuat pada batiknya tersebut. HF merupakan singkatan inisial dari nama anak-anak Haji Jamil. Sebagai generasi kedua Haji Jamil sudah sangat mengenal batik sejak beliau masih kecil. Tentunya karena orang tua $\mathrm{H}$. Jamil adalah pengusaha batik.

Suksesi bagi Haji Jamil penting untuk keberlangsungan perusahaan yang telah dirintisnya. $\mathrm{H}$. Jamil telah menyiapkan anak-anaknya untuk melanjutkan perusahaan. Saat ini, beliau 
mempersiapkan dengan melihat diantara anak-anaknya yang memiliki kecintaan kepada batik. Keturunan yang diyakini olehnya sebagai generasi penerus adalah puteri pertamanya. Hal ini tidak serta merta dipilihkan ataupun ditujukan kepada puterinya itu. Haji Jamil melihat sebuah rasa kecintaan yang ditunjukkan oleh puterinya tersebut terhadap batik, terutama usaha batik ayahnya tentunya. Anak-anaknya juga mulai menjual produk batik HF dengan sistem online. Harapannya adalah anaknya dapat membuat dan mengembangkan batik HF untuk kalangan menengah ke-atas.

\section{Batik Pesisir}

Batik Pesisir didirikan oleh H.A. Failasuf, SE sebagai pengembangan usaha batik kerajinan sutera dari keluarga besarnya. Batik Pesisir ini berlokasi di desa Kemplong, Wiradesa, Pekalongan. Failasuf merupakan generasi ke-2 dari batik pesisir ini. Sebelum berganti nama menjadi batik pesisir, dulunya adalah batik Kusuma Asih yang dikelola orang tua H.A. Failasuf. Awal memulai berdagang, seperti halnya anak-anak Pekalongan yang merantau keluar Pekalongan baik untuk bekerja maupun bersekolah, Failasuf dibekali kain batik untuk dijual. Menjual batik, menurutnya merupakan upaya untuk mempertahankan hidup dan mempertahankan pendidikan. Modalnya kain batik yang ditawarkan dari toko ke toko. Selain usaha batik sebagai sumber hidup, gaya hidup dan masa depan, tidak ada larangan dalam membuat dan memasarkan batik. Demikian menurut pandangan Failasuf.

Menurut Failasuf, sukses tidaknya bisnis batik sangat tergantung bagaimana manajemen dalam perusahaan batik dilakukan secara profesional. Menurut Failasuf, dalam perusahaan jika ingin tetap bertahan harus memiliki manajemen dan struktur yang benar dan professional. Strategi perusahaan harus dimulai dari visi, misi, perencanaan dan implementasi yang jelas. Menurutnya, hal ini jarang sekali dilakukan oleh pengusaha batik di pekalongan. Banyaknya pengusaha yang gagal, biasanya lebih kepada gaya hidup, pola manajemen yang salah dan ketidak-profesionalan pengusaha. Batik sudah memiliki sejarah dan nilai ekonomi dan komoditas. Sebagai generasi ke-dua dalam perusahaan, regenerasi juga penting untuk dilakukan di batik Pesisir. Dalam perusahaannya, Failasuf juga mempekerjakan beberapa anggota keluarga.

Menurut Failasuf, regenerasi terjadi dengan memberikan pembelajaran dan membuat mereka (anggota keluarga) tertarik mendalami batik. Failasuf mengakui telah membuat rumusan strategi regenerasi : 1) memberikan pendidikan yang baik tentang bisnis batik, 2) pendidikan organisasi sosial, kemasyarakatan dan keagamaan, 3) memberi kepercayaan untuk mencoba dalam bisnis dan sekolah, 4) memberi peluang yntyk memasarkan batik. Menurutnya hal ini perlu karena ada sebagian orang yang hanya berpikir bahwa yang penting adalah mampu berproduksi padahal ilmu marketing juga perlu. Cara berpikir perlu diubah demikain pendapatnya. Oleh karena itu cara berpikir Failasuf dengan ayahnya berbeda karena ayah hanya berpikir produksi dan dia berpikir marketing, khususnya untuk bisnis saat ini, 5) stimulasi modal dan memberi modal agar mandiri, dengan bunga ringan agar bertanggungjawab, 6) memberi pengalaman tentang bisnis, 7) menghimbau untuk mendirikan perusahaan sendiri agar memiliki tanggungjawab.

\section{Pembahasan}

Rumus sukses dalam menjalankan perusahaan keluarga adalah sukses dalam menjalankan proses suksesi. Suksesi bisnis keluarga adalah proses untuk kelanjutan bisnis keluarga yang turun dari generasi tua ke generasi yang lebih muda, termasuk didalamnya warisan properti, hak saham, operasional, reputasi dan status (Hania, 2012). Pendapat ini sangat sesuai dengan 
penuturan Haji Jamil dari batik HF, bahwasanya perusahaan keluarga harus mampu bertahan dan salah satu cara bertahan adalah pentingnya suksesi.

Batik merupakan satu budaya yang dimiliki Indonesia. Industri batik di Pekalongan saat ini berkembang pesat, terutama setelah batik mendapatkan pengakuan dari UNESCO, semakin banyak pelaku industri batik yang merupakan pemain baru dan mulai ikut bersaing dengan mengembangkan batik secara inovatif dan memiliki ciri khas masing-masing. Batik bagi masyarakat Pekalongan telah melekat erat dalam kehidupan mereka dan lingkungan sekitar yang rata-rata adalah pembatik dan penenun merupakan factor yang sangat berpengaruh dalam membentuk karakter dari masing-masing pelaku usaha batik di masa datang, yaitu keinginan yang kuat untuk meneruskan bisnis batik keluarga atau membuka bisnis batik dengan label sendiri.

Suksesi yang sukses dipandang oleh masyarakat Pekalongan terutama pada para pengusaha batik adalah ketika para pengusaha tersebut dapat meregenerasi usahanya kepada para penerusnya yaitu keturunan dari keluarganya. Hal ini dapat menjadikan pengusaha tersebut menjadi pemimpin dalam komunitasnya sebagai kelompok pengusaha batik Pekalongan. Suksesi dalam arti mampu mengentaskan dari anak cucu dan seterusnya. Umumnya, manajemen pengelolaan usaha batik dilakukan dengan pola hubungan keluarga dan juragan batik membebaskan anak-anaknya untuk membuka usaha lain tetapi tetap menjual batik.

Jika dirunut, empat perusahaan keluarga yang menjadi obyek kajian adalah perusahaan dengan tipe Family Business Enterprise (FBE), yaitu perusahaan yang dimiliki dan dikelola oleh keluarga pendiri atau keturunannya. Jika rumusan Handler (1992) dikaitkan dengan kenyataan di masing-masing perusahaan, dapat diketahui bahwa ke-empat pelaku usaha tersebut sesuai dengan tahapan pertama yaitu tahap pengembangan individu. Hal ini dimulai dengan memperkenalkan bisnis mereka kepada anak-anak sedari kecil, dengan membawa mereka ke tempat produksi, tujuannya adalah untuk menanamkan kecintaan mereka terhadap batik dan perusahaan. Dengan memiliki kecintaan terhadap batik, maka diharapkan mereka akan lebih siap dalam mengelola perusahaan.

Mengenalkan batik sedari kecil kepada anak-anak hampir sama seperti yang dilakukan oleh orangtua masing-masing pelaku usaha dimasa lalu. Diantara ke-empat pelaku usaha, hanya pak Husein yang sama sekali tidak berasal dari keluarga pembatik atau juragan batik. Bu Fat merupakan anak dari seorang juragan penenun ATBM yang mengakui bahwa sedari kecil mulai bangun tidur telah mendengar bunyi alat tenun ATBM. Haji Jamil dan Failasuf, keduanya memiliki orangtua pembatik. Yang pernah mereka alami inilah yang akhirnya membentuk mereka untuk suatu saat ketika memiliki anak, mereka juga memperkenalkan hal yang sama ke anak-anak mereka. Keterlibatan anak-anak dalam usaha batik orangtua juga tidak hanya dipengaruhi factor internal seperti diatas, akan tetapi factor eksternal yaitu lingkungan sekitar mereka yang juga merupakan pembatik. Lingkungan inilah yang menjadi suatu budaya yang melekat di masyarakat Pekalongan.

Tahap kedua menurut Handler adalah keterlibatan anak-anak dalam bisnis. Pada awalnya, $\mathrm{Bu}$ Fat dan pak Husein memberikan kesempatan kepada anak-anaknya menuntut ilmu setinggi mungkin dan memberikan keleluasaan bagi anak-anaknya untuk bekerja di perusahaan lain, dengan tujuan menyerap pengalaman mereka berbisnis dan jika sudah tiba waktunya mereka kembali ke perusahaan dan menerapkan ilmu dan pengalaman mereka. Haji Jamil telah mempersiapkan dan melibatkan anak pertamanya untuk menangani sepenuhnya bisnis perusahaan dengan mengkhususkan pengembangan batik HF pada 
konsumen menengah ke-atas (batik sutera). Sementara bu Fat melibatkan anaknya hanya untuk bagian desain dan motif, teknis lainnya masih ditentukan penuh oleh bu Fat. Pada batik Huza, pak Husein melibatkan anak-anaknya pada bagian pemasaran dan pengelolaan perusahaan, sementara Failasuf belum dalam proses suksesi karena anak-anak masih sangat kecil.

Dari pernyataan beliau tersirat bahwa beliau juga meyakini bahwa para pelaku usaha batik tersebut meyakini bahwa perusahaan harus dipegang dan dikelola langsung oleh keturunannya, akan tetapi tentu bukan hanya mengandalkan ikatan darah, akan tetapi didukung oleh kemampuan, pengalaman dan kualitas manajerial dari generasi penerus yang memiliki kecintaan terhadap batik.

Tahap ketiga menurut Handler adalah tahapan suksesi kepemimpinan (ownership succession process). Pada tahapan ini ke-empat pelaku usaha terutama pendiri batik Tobal, batik Huza dan batik HF sama sekali belum memilih siapa diantara anak mereka yang akan menjadi "Putra Mahkota". Proses suksesi yang saat ini digunakan oleh batik Tobal, batik Huza dan batik HF adalah lebih ke memfokuskan anak-anak mereka ke dalam manajemen perusahaan. Mereka tidak langsung memilih calon penerus-pengganti, tetapi lebih condong ke proses "Management Succession Process (manajemen proses suksesi)". Didalam manajemen proses suksesi melibatkan keluarga besar sebagai partisipan dalam pengambilan keputusan, dan melibatkan calon penerus didalam menangani manajemen perusahaan (Walsh, 2011). Bu Fat dan Pak Husein bahkan mengakui bahwa mereka sama sekali belum berminat untuk mundur dari perusahaan, sekalipun telah melibatkan anak-anak, mereka masih tetap ingin bekerja dan masih menjadi penentu dalam pengambilan keputusan di perusahaan masing-masing.

Berdasarkan hasil analisis data penelitian dapat dilihat bahwa para pelaku usaha industri yang terlibat dalam penelitian ini menyadari bahwa suksesi atau regenerasi sangat penting untuk dilakukan, untuk mempertahankan bisnis perusahaan yang telah dibangun. Mereka melibatkan anak-anak sedari kecil untuk mengenal batik dan perusahaan batik mereka, sama seperti yang orangtua mereka lakukan dahulu. Mereka juga mempersiapkan anak-anak dengan memberikan pendidikan hingga ke tingkat perguruan tinggi sebagai bekal mereka untuk meningkatkan kemampuan dan kualitas diri, hingga akhirnya mereka kembali untuk mengembangkan perusahaan. memiliki kemampuan pengembangan diri, integritas dan komitmen yang tinggi terhadap perusahaan.

Para pelaku usaha batik dalam penelitian ini telah berada dalam lingkungan pembatik dan penenun sejak lahir, sehingga yang pernah mereka alami inilah yang akhirnya membentuk mereka untuk suatu saat ketika memiliki anak, mereka juga memperkenalkan hal yang sama ke anak-anak mereka. Keterlibatan anak-anak dalam usaha batik orangtua juga tidak hanya dipengaruhi factor internal seperti diatas, akan tetapi factor eksternal yaitu lingkungan sekitar mereka yang juga merupakan pembatik. Lingkungan inilah yang menjadi suatu budaya yang melekat di masyarakat Pekalongan.

Dalam penelitian ini, keterlibatan anak-anak sebagai calon penerus perusahaan masih berada pada tingkat yang sedang/medium, dalam hal ini belum ada satu anak yang diarahkan untuk menjadi calon pemilik pengganti mereka, anak-anak diberikan peluang yang sama untuk masuk ke dalam manajemen perusahaan, diberikan porsi tanggungjawab masing-masing, akan tetapi pendiri masih memegang peranan yang besar terutama dalam hal pengambilan keputusan dan kebijakan yang diterapkan dalam perusahaan. Para pelaku usaha melihat 
penerus yang tepat untuk menjadi pengganti mereka adalah anak yang tidak hanya memiliki kecintaan terhadap batik, dan juga anak-anak yang mau mengembangkan usaha keluarga ke arah yang lebih professional, misal memperbaiki struktur organisasi perusahaan, membuka cabang toko dan bahkan membuka peluang franchise batik.

Hasil pemaparan keterkaitan analisis data diatas dengan teori-teori suksesi dapat dirincikan pada tabel berikut :

Tabel I : Analisis Perencanaan dan Proses Suksesi Hasil Penelitian

\begin{tabular}{|l|l|l|l|l|}
\hline $\begin{array}{r}\text { Pelaku Usaha } \\
\text { Batik }\end{array}$ & $\begin{array}{l}\text { Fatchiyah } \\
\text { (Founder of } \\
\text { Batik Tobal) }\end{array}$ & $\begin{array}{l}\text { Husein } \\
\text { (Founder } \\
\text { of Batik } \\
\text { Huza) }\end{array}$ & $\begin{array}{l}\text { Haji Jamil } \\
\mathbf{2}^{\text {nd }} \\
\text { generation } \\
\text { of Batik } \\
\text { HF) }\end{array}$ & $\begin{array}{l}\text { Failasuf } \\
\mathbf{2}^{\text {nd }} \\
\text { generatio } \\
\text { n of Batik } \\
\text { Pesisir) }\end{array}$ \\
\hline $\begin{array}{l}\text { Tipe perusahaan } \\
\text { menurut Susanto (2000) }\end{array}$ & $\begin{array}{l}\text { Family } \\
\text { Business } \\
\text { Enterprise }\end{array}$ & $\begin{array}{l}\text { Family } \\
\text { Business } \\
\text { Enterprise }\end{array}$ & $\begin{array}{l}\text { Family } \\
\text { Business } \\
\text { Enterprise }\end{array}$ & $\begin{array}{l}\text { Family } \\
\text { Business } \\
\text { Enterprise }\end{array}$ \\
\hline $\begin{array}{l}\text { Gaya Kepemimpinan } \\
\text { menurut Hoover and } \\
\text { Hoover (2009) }\end{array}$ & Push & Pull & Pull & Push \\
\hline Perencanaan Suksesi & No & No & No & No \\
\hline $\begin{array}{l}\text { Proses suksesi menurut } \\
\text { teori Handler (1992) }\end{array}$ & Middle & Middle & Middle & No \\
\hline $\begin{array}{l}\text { Keterlibatan suksesor } \\
\text { dalam perusahaan } \\
\text { menurut Walsh (2011) }\end{array}$ & Manajemen & Manajemen & Manajemen & No \\
\hline
\end{tabular}

\section{Kesimpulan}

Berdasarkan hasil penilitian eksploratif ini bisa disimpulkan bahwa perencanaan formal regenerasi belum dianggap mendesak untuk dilakukan meski para pemilik usaha menyadari bahwa regenerasi untuk menjaga kelangsungan bisnis keluarga tidak bisa dihindari. Tidakadanya perencanaan regenerasi secara formal disebabkan oleh tiga hal: Pertama, adanya anggapan dan keyakinan bahwa salah satu generasi penerus pasti ada yang bersedia untuk meneruskan bisnis orang tuanya. Kedua pada umumnya pengsuaha batik Pekalongan tergolong pada Family Business Enterprise dimana perusahaan pada umumnya dikelola secara informal. Ketiga, calon pengganti meski tidak disiapkan untuk menjadi penerus sesungguhnya sudah terbiasa dengan kegiatan bisnis baik dalam lingkungan keluarga maupu dalam lingkungan sosial sehingga calon pengganti secara tidak sadar sudah membentuk dirinya menjadi pengusaha.

Menyadari bahwa suksesi merupakan faktor penting dalam perusahaan keluarga karena pada umumnya para pendiri perusahaan menginginkan perusahaan yang telah dirintisnya tidak jatuh ke tangan orang lain, namun di saat yang sama para pendiri cenderung membiarkan generasi penerus belajar mandiri untuk melakukan kegiatan bisnis keluarga, peneliti lain disarankan untuk melanjutkan penelitian ini. Diantara topik yang masih memerlukan kajian lebih lanjut adalah bagaimana transfer of knowledge didesiminasi dari generasi pertama ke generasi kedua. Berkaitan dengan hal tersebut perlu pula dikaji value transfer dari generasi pertama ke generasi berikutnya. Selain itu hasil penelitian ini menunjukkan bahwa peran budaya telah membantu masyarakat secara tidak sadar terlibat dalam bisnis batik. Yang 
barangkali perlu dicermati peneliti lain adalah bagaimana proses pembudayaan ini berlangsung.

\section{Daftar Pustaka}

Cater III, J. J. (2006). "Stepping Out The Shadow: The Leadership Qualities Of Successors In Family Business". Unpublished Doctoral Dissertation. Proquest Information and Learning Company.

Cater III, J.J., and Justis, R.T. (2009). "The Development Of Successors From Followers To Leaders In Small Family Firms : An Exploratory Study”. Family Business Review, Volume 22 Number 2, Page 109-124. http ://fbr.sagepub.com

Chua, Jess H., James J. Chrisman and Pramodita Sharma. (1999). "Defining the Family Business by Behavior". Entrepreneurship: Theory and Practice. Summer 1999 v23 i4 p19. Baylor University. Electronic resources download: on Sunday, March $2^{\text {nd }}$, 2009. At: http://faculty.utep.edu/LinkClick.aspx?fileticket\&26055.

Chrisman, J.J., Chua, J.H., Sharma, P., and Yoder, T.R. (2009). " Guiding Family Business Through The Succession Process, A Step-by-step Guide For CPA Advisors". The CPA Journal, June 2009, page 48 -51. New York State Society of CPA.

Handler, W.C. (1994). "Succession in Family Business : A Review of The Research". Family Business Review, Volume 7, Page 133-157. Published by Sage Publications. http ://fbr.sagepub.com

Handler, W.C. (1992). “ The Succession Experience of The Next Generation”. Family Business Review, Volume 5, Page 283-307. Published by Sage Publications.http ://fbr.sagepub.com.

Hania, Mahmoud, F. (2012). “Faktor Influencing Family Business Succession Case Study : Gaza Family Business". Unpublished Thesis. Faculty of Commerce, Department of Business Administration. Islamic University - Gaza. Palestine.

Hikmahwati, Evie. (2006). “ Tantangan Suksesi dan Regenerasi Perusahaan Keluarga AlFajar. Tesis Program Pasca Sarjana, Universitas Indonesia, Jakarta.

Ibrahim, A. B., Soufani, K., \& Lam, J. (2001). A study of succession in a family firm. Family Business Review, 14(3), 245-258.

Lee, Yoon G., Jasper, Cynthia R.,and Goebel, Karen P. (2003). "A Profile of Succession Planning Among Family Business Owners". Journal Financial Counseling and Planning, Volume 14 (2).

Sekarbumi, Ananda. (2001). "Succession in Family Business in Indonesia". Unpublished Doctoral Dissertation, The Maastricht School of Management. Proquest Information and Learning Company. 
Sharma, Pramodita., Chrisman, James J., and Chua, Jess H. (2003). " Succession Planning as Planned Behaviour : Some Empirical Results". Family Business Review. Volume XVI, No.1, March.Published : Family Firm Institute, Inc.

Susanto, A.,B. (2006). "Suksesi Dalam Perusahaan Keluarga". Published by The Jakarta Consulting Company. www.jakartaconsulting.com. Diakses pada 2 Maret 2012.

Susanto, A.,B. (2006). "Family Business". Published by The Jakarta Consulting Company. www.jakartaconsulting.com._Diakses pada 2 Maret 2012.

Susanto, A., B. (2000). World class family business. Jakarta: Jakarta Consulting Group.

Sobirin, Achmad. (2012). "Pola Kepemimpinan dan Suksesi Perusahaan Keluarga Pada Industri Batik di Pekalongan". Laporan Penelitian Tahun Ke - 3 Hibah Penelitian Tim Pasca Sarjana (Hibah Pasca). Universitas Islam Indonesia, Yogyakarta.

Tambunan, Damelina., B. (2009). "The Proffesional Phenomena Of Family Business". International Business Management, Ciputra University, Surabaya, Indonesia.

Wahjono, S.I. (2009). "Suksesi Dalam Perusahaan Keluarga". http://puslit2.petra.ac.id/ejournal/index.php/unm/article/view/17158. Diakses pada 2 Maret 2012.

Walsh, Grant. (2011). "Family Business Succession, Managing of The All-Important Family Component”. Canada : KPMG Enterprise.

Ward, John, L.(2004). "Perpetuating the Family Business: 50 Lessons Learned". Journal International Small Business, December 1.

Wijaya, Trisnadi. (2011). "Materi Perkuliahan: Suksesi Dalam Perusahaan Keluarga".www.mdp.ac.id/materi/2011-2012-2/.../MI406-072153-793-9.ppt. Diakses tanggal 7 Maret 2013. 